\title{
Prostate-Specific Antigen
}

National Cancer Institute

\section{Source}

National Cancer Institute. Prostate-Specific Antigen. NCI Thesaurus. Code C17525.

Prostate-specific antigen (261 aa, $29 \mathrm{kDa}$ ) is encoded by the human KLK3 gene. This protein plays a role in both proteolysis and seminal fluid liquefaction. 